\title{
Pengaruh model pembelajaran Biologi berbasis Reading- Concept Map-Cooperative Script (Remap-Cs) dan gender terhadap keterampilan berpikir kritis dan hasil belajar kognitif siswa kelas X MIPA SMA Negeri 2 Malang
}

\author{
Shila Avila, Susriyati Mahanal*, Siti Zubaidah \\ Universitas Negeri Malang, Jl. Semarang No. 5 Malang, Jawa Timur, Indonesia \\ *Penulis korespondensi, Surel: susriyati.mahanal.fmipa@um.ac.id
}

Paper received: 02-01-2021; revised: 15-01-2021; accepted: 30-01-2021

\begin{abstract}
this research aims to: The purpose of this study is to know: 1) the effectiveness of Remap-CS based learning model towards critical thinking skills and cognitive learning outcomes of students in SMA Negeri 2 Malang; 2) the effectiveness of gender towards critical thinking skills and cognitive learning outcomes of students in SMA Negeri 2 Malang; 3) the interaction between learning model based on Remap-CS with gender to critical thinking skill and cognitive learning outcomes of students in SMA Negeri 2 Malang. The research design used was quasi experiment research with pretest- posttest nonequivalent group design. The population of research is the students of $\mathrm{X}$ class in SMAN 2 Malang. The sample of the research is the students of class X MIPA 3 as the experimental class and class X MIPA 5 as the control class. Data is taken during pretest \& posttest. The first test instrument is tested for validity and reliability. Hypothesis test using anakova with significance level 0, 05 (P is less then 0,05$)$ using pretest and posttest score data. The results showed: 1 ) there is an effect of Remap-CS biology based learning on critical skill and cognitive learning achievement in students; 2) there is no effect of gender towards critical skill and cognitive learning outcomes in students; 3 ) there is an interaction between learning strategy and gender towards critical thinking skill, but there is no effect of learning strategy and gender to students cognitive learning outcomes.
\end{abstract}

Keywords: Remap-CS; gender; critical thinking skills; cognitive learning outcomes

\begin{abstract}
Abstrak
penelitian ini bertujuan untuk mengetahui: 1) pengaruh model pembelajaran berbasis Remap-CS terhadap keterampilan berpikir kritis dan hasil belajar kognitif siswa di SMA Negeri 2 Malang; 2) pengaruh gender terhadap keterampilan berpikir kritis dan hasil belajar kognitif siswa di SMA Negeri 2 Malang; 3) pengaruh interaksi antara model pembelajaran berbasis Remap-CS dengan gender terhadap keterampilan berpikir kritis dan hasil belajar kognitif siswa di SMA Negeri 2 Malang. Rancangan penelitian yang digunakan ialah quasi eksperimen dengan pretest posttest nonequivalent group design. Populasi penelitian ialah siswa kelas X di SMAN 2 Malang. Sampel penelitian adalah siswa kelas X MIPA 3 sebagai kelas eksperimen dan kelas X MIPA 5 sebagai kelas kontrol. Data diambil pada saat pretest \& posttest. Instrumen tes terlebih dahulu diuji validitas dan reliabilitas. Uji hipotesis menggunakan anakova dengan taraf signifikansi 0,05 (P lebih kecil dari 0,05$)$ menggunakan data skor pretest dan posttest. Hasil penelitian menunjukkan: 1) ada pengaruh pembelajaran biologi berbasis Remap-CS terhadap keterampilan berpikir kritis dan hasil belajar kognitif pada siswa; 2) tidak ada pengaruh gender terhadap keterampilan berpikir kritis dan hasil belajar kognitif pada siswa; 3) ada pengaruh interaksi strategi pembelajaran dan gender terhadap keterampilan berpikir kirits, namun tidak ada pengaruh interaksi strategi pembelajaran dan gender terhadap hasil belajar kognitif siswa.
\end{abstract}

Kata kunci: Remap-CS; gender; keterampilan berpikir kritis; hasil belajar kognitif 


\section{Pendahuluan}

Pada abad 21 ini Sumber Daya Manusia (SDM) idealnya mempunyai 4 kemampuan berpikir, yaitu berpikir kritis, kreatif, kolaboratif, dan komunikatif (Partnership for 21 Century, 2002). Hal tersebut sesuai dengan penjelasan dari Badan Standar Nasional Pendidikan (2010) terkait kualifikasi Sumber Daya Manusia abad 21 yang harus mempunyai kemampuan berpikir kritis, keterampilan metakognitif, pemecahan amsalah dan komunikasi. Namun ironisnya, walaupun abad 21 telah berjalan selama 1 dekade, beberapa sekolah di Kota Malang masih kurang memberdayakan kecakapan hidup abad 21, khususnya keterampilan berpikir kritis.

Salah satu penyebab rendahnya kemampuan berpikir siswa adalah penggunaan strategi pembelajaran yang kurang memberikan kesempatan kepada siswa untuk memberdayakan kemampuan berpikirnya dan terlibat aktif dalam pembelajaran. Andriani (2013) dalam penelitiannya menambahkan bahwa sebagian besar guru di Indonesia hanya menyampaikan materi yang ada di buku teks saja tanpa mengaitkan dengan kehidupan siswa. Corebima (1999) dan Rofi'udin (2009) pun menjelaskan penyebab rendahnya kemampuan berpikir kritis siswa disebabkan oleh 2 alasan, yakni 1) pemberdayaan berpikir tidak dilakukan secara sengaja dan terencana di dalam kelas, 2) pendidikan berpikir kritis di tingkat pendidikan dasar belum tertangani secara sistematis dan dilaksanakan secara parsial. Rendahnya kemampuan berpikir tingkat tinggi dirasakan sampai tingkat pendidikan berikutnya bahkan sampai perguruan tinggi.

Pemberdayaan keterampilan berpikir tingkat tinggi sangat penting karena memiliki banyak manfaat bagi siswa. Kemampuan berpikir kritis merupakan modal penting bagi seseorang untuk mampu mengolah, mengevaluasi, dan membuat keputusan berdasarkan kemampuan, pengetahuan, dan pengalaman yang dimiliki. Informasi yang dipelajari dan diproses melalui berpikir tingkat tingkat akan diingat lebih lama dan lebih jelas daripada yang diproses melalui berpikir tingkat rendah, sehingga pada akhirnya hasil belajar siswa pun menjadi baik.

Keterampilan berpikir kritis dan hasil belajar siswa selain dipengaruhi oleh model pembelajaran juga dipengaruhi oleh gender atau jenis kelamin. Gender merupakan perbedaan yang cukup tampak di sekolah umum, namun jarang atau bahkan tidak teramati di dunia pendidikan. Idealnya siswa laki-laki dan perempuan memiliki hasil belajar yang merata, namun ternyata ada banyak penelitian yang mengungkap adanya perbedaan gender terhadap hasil belajar dan keterampilan siswa. Adapun perbedaan hasil belajar dan keterampilan antara siswa laki-laki dan perempuan tersebut dinamakan dengan konsep gap gender (Niederle \& Vesterlund, 2011).

Berdasarkan permasalahan di atas, solusi yang ditawarkan adalah dengan mencoba menerapkan model pembelajaran biologi berbasis Remap-CS. Selain mudah diterapkan, Remap-CS tersebut diyakini berpotensi memberdayakan keterampilan berpikir kritis dan hasil belajar kognitif baik pada siswa laki-laki atau siswa perempuan. Remap-CS melibatkan semua siswa untuk aktif dikelas dalam kerjasama untuk membangun pemahamannya. Berdasarkan penelitian yang dilakukan oleh Kurniawati (2016), Remap-CS merupakan model pembelajaran yang dapat memberdayakan keterampilan berpikir kritis karena dapat melatih siswa memonitor pemahamannya dan mengoreksi kesalahan pada rangkuman pasangannya. Kegiatan membaca merupakan proses memahami suatu materi dari teks yang ada 
merupakan kegiatan yang melibatkan proses kognitif siswa. Kegiatan meringkas merupakan kegiatan yang dapat meningkatkan kemampuan análisis dan integrasi materi (Carr, 1990 dan Cazier, 2010). Keunggulan lain dari Remap-CS terletak pada sintaksnya yang memungkinkan siswa belajar secara berpasangan, bisa laki-laki dengan perempuan sehingga keduanya memiliki kontribusi yang sama dalam pembelajaran.

\section{Metode}

Rancangan penelitian ini menggunakan rancangan penelitian eksperimen semu (quasi experiment). Desain penelitian yang digunakan adalah pretest posttest non equivalent control group design. Penelitian ini dilakukan dengan 2 materi, yakni kingdom animalia dan ekosistem. Populasi dalam penelitian ini adalah seluruh kelas X MIPA di SMA Negeri 2 Malang. Sampel yang digunakan dalam penelitian ini adalah kelas X MIPA 3 sebagai kelas eksperimen dan XI MIPA 5 sebagai kelas kontrol dengan strategi pembelajaran konvesional.

Instrumen yang digunakan dalam penelitian ini meliputi pengembangan perangkat dan pengembangan instrumen. Pengembangan perangkat pembelajaran terdiri dari silabus, rencana pelaksanaan pembelajaran (RPP) dan lembar kerja siswa (LKS) kelas eksperimen, serta lembar observasi keterlaksanaan sintaks. Instrumen pengukuran berupa tes. Teknik analisis data yang akan digunakan peneliti pada penelitian ini adalah analisis statistik menggunakan analisis kovarian dengan bantuan program SPSS versi 16.0 for windows yang sebelumnya dilakukan uji prasyarat yakni uji normalitas dan uji homogenitas.

\section{Hasil dan Pembahasan}

\subsection{Hasil}

\subsubsection{Hasil Uji Keterlaksanaan Pembelajaran}

Hasil analisis keterlaksanaan sintaks dapat dilihat pada Tabel 1. Hasil tersebut menunjukkan tingkat pararel data $(\mathrm{b} 1, \mathrm{~b} 2)$ memiliki $p$-value sebesar 0,942 dan tingkat koinsiden data (b1,b2,b3) memiliki $p$-value sebesar 0,012. Nilai pertama lebih besar dari 0,05, sedangkan nilai kedua lebih kecil dari 0,05. Dengan demikian, dapat diketahui bahwa kedua garis pararel dan tidak koinsiden (sejajar dan tidak berhimpitan). Hal tersebut menggambarkan bahwa sintaks pembelajaran telah terlaksana dengan konsisten. Hasil uji konsistensi terdapat pada Tabel 1.

Tabel 1. Hasil Uji Konsistensi Pembelajaran Cooperative Script

\begin{tabular}{lllllll}
\hline Model & & $\begin{array}{l}\text { Sum of } \\
\text { Squares }\end{array}$ & df & $\begin{array}{l}\text { Mean } \\
\text { Square }\end{array}$ & F & Sig. \\
\hline \multirow{2}{*}{1} & Regression & 5385,429 & 3 & 1795,143 & 14,470 &, $000 \mathrm{~b}$ \\
& b1,b2 & 0,65307695 & 1 & 0,653077 & 0,005 & 0,942 \\
& b1,b2,b3 & 1212,83916 & 2 & 606,41958 & 4,888 & 0,012 \\
& Residual & 4962,298 & 40 & 124,057 & & \\
& Total & 10347,727 & 43 & & & \\
\hline
\end{tabular}




\subsubsection{Deskripsi Umum Hasil Penelitian}

\subsubsection{Deskripsi Rata-Rata Skor Keterampilan Berpikir Kritis}

Data skor keterampilan berpikir kritis siswa diukur berdasarkan nilai Pretest yang dilakukan sebelum perlakuan (penerapan strategi pembelajaran Remap-CS) dan nilai posttest yang dilakukan setelah perlakuan. Rata-rata skor Pretest keterampilan berpikir kritis pada kelas kontrol adalah 21,368, sedangkan rata-rata skor posttest-nya adalah 35,497 . Rata-rata skor pretest pada kelas eksperimen adalah 25,368 sedangkan rata-rata Posttestnya 55,944. Rata-rata skor pretest keterampilan berpikir kritis pada gender perempuan adalah 24,662, sedangkan rata-rata skor posttest-nya adalah 45,967. Rata-rata skor pretest pada gender lakilaki adalah 20,001 sedangkan rata-rata posttest-nya 42,019. Rata-rata skor pretest keterampilan berpikir kritis pada kelas kontrol siswa laki-laki adalah 23,762, sedangkan ratarata skor posttest-nya adalah 38,461. Rata-rata skor pretest pada kelas kontrol siswa perempuan adalah 20,171 sedangkan rata-rata posttestnya 34,016. Rata-rata skor pretest keterampilan berpikir kritis pada kelas eksperimen gender laki-laki adalah 15,166, sedangkan rata-rata skor posttestnya adalah 46,593. Sedangkan untuk skor gender perempuan adalah 30,051 dan posttestnya adalah 63,308.

\subsubsection{Deskripsi Rata-Rata Skor Hasil Belajar Kognitif}

Data skor hasil belajar kognitif siswa diukur berdasarkan nilai Pretest yang dilakukan sebelum perlakuan (penerapan strategi pembelajaran Remap-CS) dan nilai Posttest yang dilakukan setelah perlakuan. Rata-rata skor pretest hasil belajar kognitif pada kelas kontrol adalah 53,333, sedangkan rata-rata skor posttest-nya adalah 49, 815. Rata-rata skor Pretest pada kelas eksperimen adalah 48,864 sedangkan rata-rata posttest-nya 70,682. Rata-rata skor pretest hasil belajar kognitif pada gender perempuan adalah 51,212, sedangkan rata-rata skor posttest-nya adalah 60,000. Rata-rata skor Pretest pada gender laki-laki adalah 51,563, sedangkan rata-rata Posttest-nya 57,500. Rata-rata skor pretest hasil belajar kognitif pada kelas kontrol siswa laki-laki adalah 51,667, sedangkan rata-rata skor posttest-nya adalah 49,444. Rata-rata skor pretest pada kelas kontrol siswa perempuan adalah 54,167, sedangkan rata-rata posttestnya 50,000. Rata-rata skor pretest hasil belajar kognitif pada kelas eksperimen gender laki-laki adalah 51,429, sedangkan rata-rata skor posttestnya adalah 67,857 . Sedangkan untuk skor gender perempuan adalah 47,667 dan posttestnya adalah 72,000 .

\subsubsection{Analisis Data}

\subsubsection{Uji Hipotesis Variabel Terikat Keterampilan Berpikir Kritis}

Ringkasan hasil perhitungan data keterampilan metakognitif ditunjukkan pada Tabel 2. Berdasarkan Tabel 4.13 diketahui bahwa $\mathrm{F}_{\text {hitumg }}$ perlakuan perbedaan model pembelajaran (kelas) adalah sebesar 36,799 dengan $p$-value $=0,000$. $p$-value $<\alpha(\alpha=0,05)$, berarti ada pengaruh model pembelajaran Remap-CS terhadap pencapaian hasil belajar kognitif siswa. $\mathrm{F}$ hitung pada perlakuan perbedaan gender adalah 1,919 dengan $p$-value $=0,173 p$-value $>\alpha$ $(\alpha=0,05)$, artinya tidak ada pengaruh gender terhadap keterampilan berpikir kritis siswa. 
Tabel 2. Ringkasan Anakova Pengaruh Model Pembelajaran dan Gender terhadap Keterampilan Berpikir Kritis

\begin{tabular}{llllll}
\hline Source & $\begin{array}{l}\text { Type III Sum of } \\
\text { Squares }\end{array}$ & df & Mean Square & F & Sig. \\
\hline Corrected Model & $6600,601 \mathrm{a}$ & 4 & 1650,150 & 28,585 &, 000 \\
Intercept & 19976,425 & 1 & 19976,425 & 346,044 &, 000 \\
XKBK & 517,023 & 1 & 517,023 & 8,956 &, 005 \\
Kelas & 3092,416 & 1 & 3092,416 & 53,569 &, 000 \\
Gender & 110,755 & 1 & 110,755 & 1,919 &, 173 \\
Kelas * Gender & 456,915 & 1 & 456,915 & 7,915 &, 007 \\
Error & 2540,033 & 44 & 57,728 & & \\
Total & 106951,481 & 49 & & & \\
Corrected Total & 9140,634 & 48 & & & \\
\hline
\end{tabular}

Tabel 3. Rangkuman Hasil Uji BNT Perlakuan Interaksi Pengaruh Model Pembelajaran dan Gender terhadap Kemampuan Berpikir Kritis

\begin{tabular}{lcccccc}
\hline Interaksi & Pretest & Posttest & Selisih & Peningkatan & $\begin{array}{l}\text { Rerata } \\
\text { terkoreksi }\end{array}$ & Notasi \\
\hline $\begin{array}{l}\text { Kontrol- } \\
\text { perempuan }\end{array}$ & 20,171 & 34,016 & 13,844 & $68,64 \%$ & 34,725 & $\mathrm{a}$ \\
$\begin{array}{l}\text { Kontrol-laki- } \\
\text { laki }\end{array}$ & 23,762 & 38,461 & 14,699 & $61,86 \%$ & 38,313 & $\mathrm{a}$ \\
$\begin{array}{l}\text { eksperimen- } \\
\text { laki-laki } \\
\text { eksperimen- }\end{array}$ & 15,166 & 46,593 & 31,427 & $207,22 \%$ & 48,496 & $\mathrm{~b}$ \\
perempuan & 30,051 & 60,308 & 30,257 & $100,69 \%$ & 58,658 & $\mathrm{c}$ \\
\hline
\end{tabular}

\subsubsection{Uji Hipotesis Variabel Terikat Hasil Belajar Kognitif}

Ringkasan hasil perhitungan data keterampilan metakognitif ditunjukkan pada Tabel 3. Berdasarkan Tabel 4.13 diketahui bahwa $\mathrm{F}_{\text {hitumg }}$ perlakuan perbedaan model pembelajaran (kelas) adalah sebesar 36,799 dengan $p$-value $=0,000$. $p$-value $<\alpha(\alpha=0,05)$.

Tabel 4. Ringkasan Anakova Pengaruh Model Pembelajaran dan Gender terhadap Hasil Belajar Kognitif

\begin{tabular}{llllll}
\hline & $\begin{array}{l}\text { Type III Sum of } \\
\text { Squares }\end{array}$ & df & Mean Square & F & Sig. \\
\hline Corrected Model & $5411,415 \mathrm{a}$ & 4 & 1352,854 & 12,133 &, 000 \\
Intercept & 7804,308 & 1 & 7804,308 & 69,995 &, 000 \\
XHBK & 49,148 & 1 & 49,148 &, 441 &, 510 \\
Kelas & 4103,054 & 1 & 4103,054 & 36,799 &, 000 \\
Gender & 55,578 & 1 & 55,578 &, 498 &, 484 \\
Kelas * Gender & 23,010 & 1 & 23,010 &, 206 &, 652 \\
Error & 4905,932 & 44 & 111,498 & & \\
Total & 181950,000 & 49 & & & \\
Corrected Total & 10317,347 & 48 & & & \\
\hline
\end{tabular}


Tabel 4.5. Rangkuman Hasil Uji BNT Perlakuan Interaksi Pengaruh Model Pembelajaran dan Gender terhadap Hasil Belajar Kognitif

\begin{tabular}{lllllll}
\hline Interaksi & Pretest & Posttest & Selisih & Peningkatan & $\begin{array}{l}\text { Rerata } \\
\text { terkoreksi }\end{array}$ & Notasi \\
\hline Kontrol-laki-laki & 51,667 & 49,444 & $-2,222$ & $-4,30 \%$ & 49,478 & $\mathrm{a}$ \\
Kontrol-perempuan & 54,167 & 50,000 & $-4,167$ & $-7,69 \%$ & 50,279 & $\mathrm{a}$ \\
$\begin{array}{l}\text { Eksperimen-laki- } \\
\text { laki }\end{array}$ & 51,429 & 67,857 & 16,429 & $31,94 \%$ & 67,867 & $\mathrm{~b}$ \\
$\begin{array}{l}\text { Eksperimen- } \\
\text { perempuan }\end{array}$ & 47,667 & 72,000 & 24,333 & $51,05 \%$ & 71,64 & $\mathrm{~b}$ \\
\hline
\end{tabular}

\subsection{Pembahasan}

\subsubsection{Pengaruh Strategi Pembelajaran Remap-CS terhadap Keterampilan Berpikir Kritis dan Hasil Belajar Kognitif}

Berdasarkan analisis anakova diketahui bahwa model pembelajaran biologi berbasis Reading-Concept Map-Cooperative Script (Remap-CS) dan pembelajaran konvensional memberikan hasil yang berbeda nyata terhadap variabel terikat yang meliputi keterampilan berpikir kritis dan hasil belajar kognitif. Hasil uji lanjut menunjukkan model pembelajaran biologi berbasis Remap-CS mempunyai rata-rata terkoreksi keterampilan berpikir kritis lebih tinggi daripada pembelajran konvensional. Hal tersebut dapat disebabkan oleh faktor sintaks Remap-CS yang dapat menunjang pemberdayaan terhadap keterampilan berpikir kritis dan hasil belajar kognitif siswa. Sintaks pembelajran Remap-CS terdiri atas membaca (understanding by reading), menyusun ringkasan hasil membaca dalam bentuk peta konsep (mention key ideas in concept map), menjelaskan peta konsep kepada teman, mengoreksi dan memberikan saran perbaikan terhadap peta konsep milik teman (monitor), melakukan elaborasi (elaborate), dan yang terakhir adalah menyusun ringkasan dalam bentuk peta konsep dari hasil pembelajaran (review).

Pembelajaran Remap-CS diawali dengan pemberian tugas membaca materi sesuai tema yang ditentukan oleh guru pada pertemuan sebelumnya. Membaca merupakan aktivitas intelektual yang dapat melibatkan pembaca untuk memahami dan memproses informasi (Sharma \& Singh, 205). Sejalan dengan Sharma \& Singh, Zamzani dan Munoto (2013) juga menjelaskan bahwa ketika siswa diminta untuk membaca, maka siswa akan terbiasa untuk belajar dari berbagai sumber belajar untuk memperoleh informasi. Hussain \& Munshi (2011) menjelaskan bahwa membaca dapat meningkatkan level informasi dan pengetahuan siswa.

Kegiatan siswa setelah membaca adalah menyusun ringkasan dalam bentuk peta konsep. Siswa harus fokus terhadap tema atau topik yang sedang dipelajari dalam melakukan pemilihan ide pokok atau informasi untuk menyusun peta konsep. Kegiatan yang mengharuskan siswa untuk fokus terhadap suatu topik atau tema merupakan kegiatan yang dapat mendorong dimilikinya keterampilan berpikir kritis. Ennis (1993) menjelaskan bahwa fokus terhadap permasalahan merupakan salah satu indikator berpikir kritis. Siswa harus dapat memilih infomasi yang relevan dan mengidentifikasi ide pokok dari bacaan untuk dapat menyusun peta konsep. Memilih informasi yang relevan merupakan salah satu proses 
pembelajaran yang dapat memberdayakan keterampilan berpikir kritis (Ennis, 1993; Eggen \& Kauchak, 2012).

Manfaat meringkas bacaan yang dapat memberdayakan keterampilan berpikir kritis juga dijelaskan oleh Suryani, dkk. (2013) yang menjelaskan bahwa meringkas dapat melatih siswa mengembangkan ide-idenya, sehingga siswa dapat mengonstruksi sendiri pengetahuan. Meringkas sebagai salah satu kegiatan esensial dalam Remap-CS memiliki manfaat dalam pemberdayaan keterampilan berpikir kritis. Meringkas atau menulis kembali poin penting informasi yang telah didengar, dilihat, atau dibaca dapat menjadi suatu proses berpikir tingkat tinggi. Hal tersebut dapat menjadi semakin baik jika kegiatan meringkas tersebut dilakukan sebagai suatu kebiasaan. Meringkas itu sendiri juga merupakan bentuk aktivitas kognitif yang menantang, karena dalam waktu sekaligus membutuhkan memori yang kuat, kemampuan berbahasa, dan kemampuan berpikir yang baik.

Siswa menyusun ringkasan dalam bentuk peta konsep. Kelebihan penggunaan peta konsep tersebut bagi siswa adalah dapat memberikan kesempatan bagi siswa untuk berpikir tentang hubungan antara istilah sains yang sedang dipelajari, mengorganisasi pemikiran dan memvisualisasikan hubungan diantara konsep penting dengan cara yang sistematis, dan juga mengarahkan siswa untuk dapat merefleksikan pengetahuan yang sedang atau telah dipelajari. Semakin rumit susunan peta pada peta konsep dapat memperlihatkan semakin tinggi struktur integrasi pengetahuan siswa. Edmonson \& Smith (1996) menjelaskan bahwa meringkas hasil membaca dalam bentuk peta konsep dapat memfasilitasi siswa untuk melakukan pengorganisasian informasi secara hirarkis, mengklarifikasi serta memperbaiki konsep yang dimiliki.

Proses penyusun peta konsep merupakan dalah satu kegiatan belajar yang mendorong siswa untuk mnegontruksi pengetahuan dan meningkatkan pemahaman terhadap materi (Kinchin \& Hay, 2000; Edmonson \& Smith, 1996). Peta konsep dapat membantu siswa menemukan hubungan antar konsep-konsep, mengorganisasikan pikiran, dan memvisualisasikan hubungan antara konsep satu dengan konsep lainnya secara sistematis (Vanides, et al., 2005). Siswa memerlukan pemikiran yang sekadar tidak mengetahui, memahami, namun harus dapat menerapkan dan menganalisis hubungan antara konsep. Rangkaian proses kognitif yang harus dilakukan siswa dalam menyusun peta konsep dapat berkontribusi terhadap hasil belajar kognitif yang baik. Pembelajaran yang menerapkan penggunaan peta konsep dapat meningkatkan kemampuan siswa dalam menguasai konsep (Purwianingsih, 2014).

Pada strategi Remap-CS, ringkasan dalam bentuk peta konsep yang telah dibuat oleh masing-masing siswa dibacakan kepada pasangan untuk kemudian dikomentari, dikoreksi dan didiskusikan. Mendiskusikan hal-hal yang telah dipelajari dengan siswa lain membantu memperbaiki pengetahuan yang dimiliki dan tingkat berpikirnya. Aktivitas diskusi juga memungkinkan pemahaman menjadi lebih jelas serta memperkaya informasi yang dipelajari (Hawkins, 2010). El Koumy (2006) menjelaskan bahwa informasi yang baru didapatkan siswa dari teman dapat digunakan untuk memodifkasi pengetahuan yang dimiliki. Siswa dapat menjadi lebih memahami materi yang sedang dipelajari.

Siswa saling mengoreksi dan memperbaiki hasil ringkasan pada tahap monitor. Siswa dapat melakukan koreksi dan perbaikan jika siswa mampu mengidentifikasi permasalahan dari hasil ringkasan yang telah disusun oleh teman sekelompok, kemudian 
dapat mengkomunikasikan dengan baik ide untuk perbaikan dan saran bagi teman. Hal tersebut menurut Duron et al. (2006) merupakan bagian dari keterampilan berpikir kritis. Berkaitan dengan keterampilan berpikir kritis, mengoreksi apa yang telah diringkas oleh temannya dapat digunakan untuk memberdayakan keterampilan berpikir kritis, karena siswa dituntut untuk membutuhkan kemampuan pengambilan informasi dengan cepat, menganalisis, menilai dan mengevaluasi hasil rangkuman teman, mana saja yang sudah benar dan mana yang belum.

Siswa melakukan elaborasi atau menguraikan ide terhadap hasil membaca dan menyusun peta konsep setelah melakukan tahap pembelajaran menjelaskan dan mengoreksi. Kegiatan elaborasi difaslilitasi dengan kegiatan diskusi untuk menyelesaikan permasalahan berdasarkan hasil membaca. Berdiskusi juga merupakan salah satu aktivitas yang berpotensi meningkatkan keterampilan berpikir kritis.

Siswa memerlukan pemikiran yang dalam untuk mengidentifikasi informasi mana yang akan digunakan untuk menyelesaikan permasalahan dan mengaitkan informasi atau pengetahuan yang dimiliki dengan informasi lain dari berbagai sumber untuk menyelesaikan permasalahan. Proses pengelolaan informasi dalam diri siswa dapat mendorong siswa untuk dapat memiliki keterampilan berpikir kritis.

Tahap terakhir dalam pembelajara tatap muka Remap-CS adalah menyusun ringkasan. Ringkasan dapat disusun berdasarkan pengetahuan dan pengalaman belajar. Menyusun ringkasan memerlukan keterampilan untuk melakukan pemilihan terhadap konsep-konsep yang harus dimasukkan ke dalam ringkasan. Kegiatan memilih informasi yang relevan merupakan salah satu keterampilan berpikir kritis (Ennis, 1993). Siswa juga dapat memantau serta mengevaluasi perkembangan pengetahuan dan keterampilan pada diri melalui kegiatan meringkas. Lebih lanjut dijelaskan bahwa siswa dapat membandingkan pengetahuan diri dengan pengetahuan yang didapatkan teman. Siswa dapat melakukan evaluasi terhadap diri meliputi apakah terhadap konsep yang perlu diperbaiki dan informasi apa saja yang perlu ditambahkan.

Pembelajaran CS selain dapat meningkatkan keterampilan berpikir kritis, ternyata juga dapat meningkatkan hasil belajar kognitif siswa pada mata pelajaran biologi. Pembelajaran CS memiliki sintaks yang mengharuskan siswa untuk membaca, meringkas, mengoreksi, mengelaborasi, menyusun kesimpulan, dan bekerja secara kooperatif dapat memfasilitasi siswa untuk dapat memperoleh pengetahuan, menghubungkan pengetahuan yang didapatkan dengan pengetahuan yang telah dimiliki, bertanggung jawab secara individu untuk memahami materi. Melalui serangkaian kegiatan pembelajaran tersebut siswa dapat memperoleh keterampilan berpikir kritis yang baik terhadap materi pembelajaran sehingga hasil belajar kognititf siswa pun dapat semakin baik.

\subsubsection{Pengaruh Gender terhadap Keterampilan Berpikir Kritis dan Hasil Belajar Kognitif}

Hasil analisis data mengenai pengaruh gender terhadap kemampuan berpikir kritis menggunakan uji anakova memperoleh nilai signifikansi sebesar 0,173 , sedangkan pengaruh gender terhadap hasil belajar kognitif memperoleh nilai signifikansi sebesar 0,484. Hasil tersebut memberikan makna bahwa tidak ada perbedaan secara signifikan dalam aspek kemampuan berpikir kritis dan hasil belajar kognitif pada siswa laki-laki dan siswa 
perempuan kelas X SMA Negeri 2 Malang. Hasil penelitian ini sesuai dengan penelitian dari Hadiyanti (2016) yang melaporkan bahwa tidak ada pengaruh gender terhadap keterampilan berpikir kritis, motivasi, dan karakter siswa SMA Malang. Penelitian dari Kettler (2014) yang menggunakan Cornell Critical Thinking Test dan Test of Critical Thinking menunjukkan tidak adanya pengaruh perbedaan jenis kelamin terhadap keterampilan berpikir kritis siswa.

Tidak adanya pengaruh gender dalam penelitian ini (kemampuan berpikir kritis dan hasil belajar kognitif yang sama antara siswa laki-laki dan perempuan) dapat disebabkan oleh karakter strategi pembelajaran kooperatif yang ditterapkan. Salah satu ciri khas pembelajaraan kooperatif adalah heterogenitas dalam kelompok, termasuk dalam hal jenis kelamin. Selama penerapan strategi kooperatif, dalam hal ini adalah Remap-CS, semua siswa baik laki-laki maupun perempuan dikondisikan untuk saling bekerja sama untuk megembangkan kemampuan berpikirnya. Eggen \& Kauchack (1996) memaparkan bahwa dengan pembelajaran kooperatif, maka setiap individu akan mendapatkan kesempatan yang sama untuk sukses dan mendapat hasil belajar yang baik.

Selama proses pembelajaran siswa dituntut untuk berpikir secara mandiri dan berdiskusi untuk menyelesaikan soal-soal yang ada pada lembar kegiatan siswa dalam kelompok heterogen yang telah ditentukan. Semua siswa baik laki-laki maupun perempuan akan lebih aktif menemukan penyelesaian dari semua masalah-masalah otentik yang disajikan karena anggota kelompok akan bekerja sama untuk mendapatkan temuan atau jawaban terbaik dari setiap permasalahan, mempresentasikan hasil, dan berkompetisi untuk menjadi kelompok terbaik pada saat pembelajaran berlangsung.

Selain mengenai heterogenitas kelompok, kesetaraan kemampuan berpikir siswa lakilaki dan perempuan juga disebabkan oleh pembelajaran Remap-CS yang mana harus ada saling mengoreksi peta konsep antar teman. Salah satu keunggulan dari pembelajaran biologi berbasis Remap-CS adalah membuat individu menjadi pemilik informasi yang unik. Ssetiap siswa dituntut untuk berpikir secara mandiri dan berdiskusi untuk menyelesaikan soal-soal yang ada pada lembar siswa bersama kelompoknya, sehingga setiap siswa laki-laki dan perempuan memiliki kesempatan yang sama untuk mendapat keterampilan berpikir dan hasil belajar yang baik.

Tidak adanya pengaruh gender terhadap keterampilan berpikir kritis bisa juga disebabkan oleh sintaks pada pembelajaran Remap-CS yang dilakukan oleh guru. Pembuatan ringkasan dalam bentuk peta konsep lebih berperan untuk kecerdasan spasial pada laki-laki, sedangkan pelajaran biologi sendiri menurut Vassilou (2009) merupakan pembelajaran yang bersifat feminis yang banyak mengandung kata-kata (verbal), di mana perempuan lebih unggul. Hal tersebut menyebabkan tidak adanya pengaruh gender, karena dalam hal ini lakilaki bisa mengimbangi perempuan dengan adanya peta konsep yang diberikan pada sintaks pembelajaran Remap-CS.

Seperti penelitian yang dilakukan oleh Maccoby \& Jackin (1974) menemukan bahwa dari remaja laki-laki umumnya menunjukkan kinerja yang lebih baik di visuo-spasial dan kemampuan matematika sedangkan perempuan lebih baik terhadap tugas-tugas verbal, seperti menulis kalimat, ejaan benar, membaca dan pengucapan. 


\subsubsection{Pengaruh Interaksi Strategi Pembelajaran Remap-CS dengan Gender terhadap Keterampilan Berpikir Kritis dan Hasil Belajar Kognitif}

Hasil penelitian menunjukkan bahwa ada pengaruh interaksi antara model pembelajaran Remap-CS dengan gender terhadap keterampilan berpikir kritis. Hasil uji BNT menunjukkan bahwa siswa perempuan yang menerima pembelajaran di kelas eksperimen memiliki pencapaian keterampilan berpikir kritis yang secara signifikan lebih tinggi dari siswa-siswa lainnya. Adanya interaksi antara strategi pembelajaran dengan gender terhadap kemampuan berpikir kritis didukung oleh penelitian yang pernah dilakukan oleh Mahanal (2009) yang menunjukkan bahwa terdapat interaksi antara strategi pembelajaran dan gender terhadap kemampuan berpikir kritis. Berdasarkan temuan tersebut mengindikasikan bahwa strategi pembelajaran dan gender merupakan faktor yang saling mendukung dalam meningkatkan kemampuan berpikir kritis.

Sintaks pada pembelajaran Remap-CS mendorong siswa untuk meningkatkan kemampuan berpikir kritis. Melalui pembelajaran Remap-CS siswa dapat mengeksplor pengetahuannya melalui kegiatan membaca di rumah, lalu ssiswa membuat ringkasan dalam bentuk peta konsep. Kegiatan membuat ringkasan akan melatih siswa dalam memfilter informasi. Tahapan mengoreksi kesalahan teman juga membuat siswa mampu menggunakan pengetahuannya utuk membenarkan kesalahan yang dibuat oleh tulisannya teman yang menjadi pasangannya dalam kelompok (Carr, 1990 dan Cazier, 2010).

Gender merupakan variabel yang bisa mempengaruhi keterampilan berpikir kritis siswa. Halpern \& LaMay (2000) menemukan perbedaan kecerdasan antara siswa laki-laki dan perempuan. Laki-laki dan perempuan menunjukkan perbedaan kemampuan kognitif dan keterampilan. Mahanal (2009) menemukan nilai perempuan lebih tinggi dari nilai laki-laki dalam hal kemampuan berpikir kritis analisis. Lebih lanjut perempuan juga dinilai lebih tinggi dari laki-laki dalam hal kemampuan membuat kesimpulan, yang mana perempuan lebih mampu untuk mnegidentifikasi hubungan antar variabel, menarik kesimpulan, menyusun hipotesis, mempertimbangkan informasi yang relevan, dan menganalisis data (Ricketts \& Rud, 2004).

Hasil penelitian juga menunjukkan bahwa tidak ada pengaruh interaksi antara model pembelajaran Remap-CS dengan gender terhadap hasil belajar kognitif siswa. Hasil ini senada dengan penelitian yang dilakukan oleh Ramdiah (2013). Strategi pembelajaran Remap-CS menuntut siswa untuk terlibat aktif dalam materi yang dibacanya, membuat ringkasan dalam bentuk peta konsep, mengoreksi peta konsep punya teman, elaborasi hingga mereview kembali bahan bacaan. Tahapan-tahapan ini menggambarkan bahwa siswa harus fokus ketika membaca dan mengambil ide pokok untuk membuat peta konsep, menganalisis dengan cara mengoreksi peta konsep pasangan hingga aktivitas diskusi yang dilakukan pada tahap elaborasi, sehingga dapat membantu siswa dalam upaya mengembangkan keterampilan berpikir kritisnya. Kegiatan-kegiatan tersebut tidak terlepas dari faktor gender, karena masing-masing memiliki karakteristik sendiri sehingga berpengaruh terhadap keputusan yang diambil. 


\section{Simpulan}

Berdasarkan hasil penelitian dapat diambil kesimpulan bahwa (1) Ada pengaruh pembelajaran biologi berbasis Remap-CS terhadap keterampilan berpikir kritis dan hasil belajar kognitif pada siswa. Keterampilan berpikir kritis dan hasil belajar kognitif siswa yang difasilitasi pembelajaran bioloi berbasis Remap-CS memiliki rata-rata terkoreksi lebih tinggi daripada yang difasilitasi pembelajaran konvensional. (2) Tidak ada pengaruh gender terhadap keterampilan berpiir kritis dan hasil belajar kognitif pada siswa. (3) Ada pengaruh interaksi strategi pembelajaran dan gender terhadap keterampilan berpikir kirits, namun tidak ada pengaruh interaksi strategi pembelajaran dan gender terhadap hasil belajar kognitif siswa. Kombinasi model pembelajaran Remap-CS dengan gender perempuan memiliki ratarata terkoreksi keterampilan berpikir kritis dan hasil belajar kognitif yang lebih tinggi daripada ketiga kelompok kombinasi yang lain.

Berdasarkan penelitian yang telah dilakukan, saran yang dapat diajukan adalah sebagai berikut. (1) Guru harus berusaha untuk mengontrol dan memantau perkembangan setiap siswa, khususnya untuk siswa yang sering kali tidak mengikuti pembelajaran di kelas, baik karena tidak masuk sekolah atau karena meminta izin adanya kegiatan organisasi sekolah saat jam pelajaran berlangsung. (2) Sekolah yang mayoritas siswanya didominasi oleh siswa laki-laki atau siswa perempuan, Remap-CS ini dapat digunakan sebagai pembelajaran untuk mensejajarkan keterampilan berpikir kritis dan hasil belajar kognitif siswa dengan gender yang berbeda. Dengan demikian, kesenjangan antara nilai siswa perempuan dan laki-laki dapat dikurangi. (3) Pengaruh gender terhadap kemampuan berpikir kritis dan hasil belajar kognitif dengan penerapan strategi pembelajaran Remap-CS perlu diteliti lebih lanjut pada jenjang pendidikan yang berbeda.

\section{Daftar Rujukan}

Andriani, N. I. (2013). Pengaruh Penerapan Model Pembelajaran Cooperative Script Terhadap Kemampuan Berpikir Kritis \& hasil Belajar Siswa Kelas XI SMA di Kota Malang. Skripsi tidak diterbitkan. Malang: FMIPA Universitas Negeri Malang.

Carr, K. S. (1990). How Can We Teach Critical Thinking, Eric Digest. (online)

Cazier, J.D. (2010). Fostering Critical Thinking. (online)

Corebima, A.D. (1999). Proses \& Hasil Pembelajaran MIPA di SD, SLTP, \& SMU: Perkembangan Penalaran Siswa tidak Dikelola secara Terencana (Studi Kasus di Malang, Yogyakarta, \& Bandung). Makalah disajikan dalam Seminar Peningkatan Kualitas Pendidikan MIPA. Direktorat Jendral Pendidikan Tinggi Dekdikbud JICA-IMSTEP, Bandung, 11 Agustus.

Duron, R., Limbach, B., \& Waugh, W. (2006). Critical Thinking Framework For Any Discipline. International Journal of Teaching and Learning in Higher Education, 17 (2): 160-166.

Edmosom, K. M. \& Smith, D. F. (1996). Concept Map to Faciliate Veterinary Students Understanding of Fluid and Electrolyte Disorders. Makalah diseminarkan pada Annual Meeting of the American Education Research Association. New York.

Eggen, P. \& Kauhack, D. (1996). Strategi \& Model Pembelajaran: Mengajarkan Konten \& Keterampilan Berpikir Edisi ke 6. Jakarta Barat: PT. Indeks.

El-Koumy, ASAK. (2006). The Effects of the Directed Reading-Thinking Activity on EFL Students' Referential and Inferential Comprehention. (Online). (files.eric.ed.gov/fulltex/ED502645.pdf), diakses 22 Mei 2017.

Ennis, R. H. (1993). Critical thinking Assessment. Theory Into Practice, 32 (3): 179-186.

Halpern, D. F. \& Marin, L. M. (2011). Pedagogy for Developing Critical Thinking in Adolescents: Explicits Instruction Produces Greatest Gains. Thinking Skills and Creativity, 6 (-): 1-13.

Handiyanti, P. O. (2016). Pengaruh Strategi Pembelajaran Problem Based Learning (PBL), Reading Questioning and Answering (RQA), PBLdipadu RQAdan Perbedaan Jenis Kelamin pada Pembelajaran Biologi 
terhadap Keterampilan Berpikir Kritis, Motivasi, dan Karakter Siswa SMA di Kota Malang. Disertasi tidak Diterbitkan. Malang: Universitas Negeri Malang.

Hawkins, M. (2010).How To Retain What You Learn. (Online). (http://www.alpinelink.com/Leadership_Sales_Management_Consulting_Papers_Tools_Templates.aspx),diakses tanggal 8 Januari 2017.

Hussain, I. \& Munshi, P. (2011). Identifying Reading Preferences of Secondary School Students. Creative Education, 2 (5): 429-434.

Kurniawati, Z., L. (2016). Pengaruh Model Pembelajaran biologi Berbasis Reading Concept Map Cooperative Script (REMAP-CS) \& kemampuan Akademik Terhadap Keterampilan Metakognitif, Keterampilan Berpikir Kritis, \& Hasil Belajar Kognitif Siswa Kelas X MIA SMA Negeri Kota Batu. Tesis Tidak Ditebitkan. Malang: Universitas Negeri Malang.

Maccoby, E., and Jacklin, C. (1974). The psychology of sex differences. Vol. 1. Stanford, CA: Stanford University Press.

Mahanal, S. (2009). Strategi Pembelajaran Biologi, Gender dan Pengaruhnya Terhadap Kemampuan Berpikir Kritis. Makalah disampaikan pada Seminar Nasional IX Pendidikan Biologi FKIP UNS.

Niederle, M. \& Vesterlund, L. (2011). Gender and Competition. Annual Review of Economics. 3: 601-630.

Partnership for 21 ${ }^{\text {st }}$ Ceentury Skills. (2002). Learning for the 21st Century. A Report and MILE Guide for 21st Century Skills. (Online), (www.21centuryskills.org.P21.Report.pdf), diakses 19 Mei 2017.

Ramdiah, Siti. (2013). Pengaruh Strategi Pembelajaran Pq4r Terhadap Keterampilan Metakognitif \& Hasil Belajar Biologi Siswa Putra \& Putri Kelas XI SMA Di Kota Banjarmasin. Seminar Nasional X Pendidikan Biologi FKIP UNS.

Rofi'udin, A. (2009). Model pendidikan Berpikir Kritis-Kreatif untuk Siswa Sekolah Dasar. (Online). http://www.infodiknas.com/model-pendidikan-berpikir-kritis-kreatif-untuk-siswa-sekolah-dasar2.html. diakses tgl 6 Februari 2017.

Sharma, A. K. \& Singh, S. P. (2005). Reading Habits of Faculty Members in Natural Sciences: A Case Study of The University of Delhi. Annuals of Library and Information Studies, 52 (-): 140-150.

Suryani, N. K., Atmaja, INB., \& Natajaya, I. N. (2013). Pengaruh Model Pembelajaran Cooperative Script terhadap Hasil Belajar Sosiologi Ditinjau dari Motivasi berprestasi Siswa kelas X SMA PGRI 1 Amlapura. E-Journal Program Pascasarjana Universitas Pendidikan Ganesha Program Studi Administrasi Pendidikan, 4 (-): - .

Zamzani, R. \& Munoto. (2013). Pengaruh Teknik Pembelajran Cooperative Script terhadap Hasil Belajar Siswa pada Mata Diklat Menerapkan Dasar-Dasar Elektronika Pada Siswa Kelas X TAV di SMK Negeri 1 Sidoarjo. Jurnal Pendidikan Teknik Elektro. 02 (1): 343-350. 